\title{
Can Personality Traits Modulate Student Engagement with learning and their Attitude to Employability?
}

\author{
Adam Qureshi $^{\mathrm{a}^{*}}$, Helen Wall ${ }^{\mathrm{a}}$, Joyce Humphries ${ }^{\mathrm{a}}$ and Alex Bahrami Balani ${ }^{\mathrm{a}}$ \\ ${ }^{a}$ Department of Psychology, Edge Hill University, Ormskirk, United Kingdom \\ *Corresponding author: Email: qureshia@edgehill.ac.uk
}

The authors wish to thank the students at Edge Hill University for their participation in the research and all the staff who participated in this research. 


\title{
Can Personality Traits Modulate Student Engagement With Learning And Their Attitude To Employability?
}

\author{
Student engagement in Higher Education is the focus of considerable research, \\ particularly in terms of predicting educational achievement and retention. Less \\ research has examined the predictors of engagement. The current study (students \\ $N=117$, staff $N=35$ ) explores the predictive role of personality in a \\ multidimensional model of engagement. Given recent tensions between the \\ importance of employability and the time academics have to deliver this, a \\ second objective was to examine the correlation between student and staff \\ perceptions of employability. Results found no differences between student and \\ staff attitudes towards employability and further revealed that students' attitudes \\ became less positive over time. Differential patterns of trait relations were found \\ for components of engagement, though agreeableness and conscientiousness \\ were consistent predictors. Findings of individual differences are encouraging in \\ terms of integrating different practices so that different personalities can be \\ engaged. Finally, the decrease in students' attitudes towards engagement and \\ employability highlights important areas for future investigation.
}

Keywords: Employability, personality, student engagement, staff attitude.

\section{Introduction}

The rising pressure in Higher Education (H.E.) for accountability in student learning (Bok, 2006) and enhanced retention rates (Fowler \& Boylan, 2010) highlights a need to understand the key predictors of student engagement. Student engagement refers to enthusiasm, inspiration from study, and a mental resilience when studying (Schaufeli, Salanova, Gonzalez-Roma, \& Bakker, 2002), and has been shown to predict key outcomes such as grades and persistence (Astin, 1993; Kuh, 2001, 2003) and students' learning (Mega, Ronconi, \& DeBeni, 2014). A number of variables such as IQ (Furnham, Monsen \& Ahmetoglu, 2009), preferred learning styles and instruction method (Zhang \& Huang, 2001) have been associated with engagement, highlighting 
the importance of individual differences. In support, Kuh, Cruce, Shoup, Kinzie, and Kinzie (2008) suggest that activities designed to encourage engagement may not have the intended effect if not tailored to the individual. Similarly, if the specific aspects of engagement that need encouraging are not identified, the activity may not have its intended effect. Importantly, previous research focuses on engagement as a predictor of educational outcomes but less research has examined predictors of engagement. Given the oft cited role of individual differences (Farsides \& Woodfield, 2006) and student attitudes (Gaitán, 2012) in educational settings, the present study explores the relationship between students' personality traits, attitudes towards employability and student engagement.

The concept of student engagement has been defined in numerous ways and has its historic roots in work on student involvement (see Trowler, 2010). More recently, the term has come to be viewed as multi-dimensional with models of engagement capturing cognitive, behavioural and emotional aspects (e.g. Fredricks, Blumenfield \& Paris, 2004; Harper \& Quaye, 2009; Skinner, Furrer, Marchand, \& Kindermann, 2008). Cognitive engagement refers to self-regulated approaches to learning (Fredericks et al., 2004). Emotional aspect of engagement includes feelings linked with learning activities such as interest whereas behavioural engagement refers to activity levels such as effort and persistence (Mayer \& Turner, 2002). Supporting this, quality learning has been posited to rely on behaviours and emotions such as enjoyment of educational tasks, persistence and exertion (Meyer \& Turner, 2002). More specifically, Skinner and colleagues (2008) have conceptualised engagement in motivational terms (i.e., students' active participation in the classroom; see also Pierson \& Connell, 1992; Wentzel, 1993). However, Lawson and Lawson (2013) have argued that the concept of engagement 
should extend beyond institutional boundaries, as family, peer and societal relationships can impact on students' opportunities and interests.-Given our focus on individual level factors such as attitudes towards employability and personality traits, the present study focuses on psychological aspects of engagement (e.g., attitudes towards employability and personality traits) at an individual level. Therefore, the first aim of this study is to investigate the role of individual differences on student engagement using a multidimensional model.

\section{Individual Differences and Engagement: The Role of Personality}

Research has predominantly focused on engagement as a predictor of objective outcomes such as achievement and grades rather than on engagement itself as the outcome. Given the negative relations found between engagement and outcomes such as burnout (Maslach, Shaufeli, \& Leiter, 2001) there is a pressing need for research that directly examines the individual difference correlates of engagement. Hence, the present study explores the role of students' "Big-5" personality traits (Costa \& McCrae, 1992) on their engagement. Big-5 or "the Five Factor Model" of personality (FFM: Costa \& McCrae, 1992) has been accepted as the dominant model for categorising individual differences in personality (Ozer \& Benet-Martinez, 2006). The FFM suggests that individual differences in behaviour should be classified in terms of five independent traits, namely extraversion, agreeableness, conscientiousness, emotional stability and imagination; which reflect an individual's characteristic patterns of thought, emotion and behaviour (Chamorro-Premuzic \& Furnham, 2008; Costa \& McCrae, 1992;

Digman, 1990; McCrae \& Costa, 1997). The trait of extraversion encompasses facets such as sociability, assertiveness, activity, cheerfulness, and gregariousness. Agreeableness is associated with being cooperative, courteous, trusting, flexible, and 
kind. Conscientiousness denotes dependability, organization, persistence, delay of gratification and achievement-orientation. Neuroticism concerns facets such as, anxiety, and avoidance of stressful situations. Openness concerns flexibility in thinking, fantasy, openness to new ideas and interest in aesthetics (Costa \& McCrae, 1992) ${ }^{1}$.

The role of personality in academic achievement is well documented (e.g., Farsides \& Woodfield, 2006). In particular, conscientiousness has consistently and positively been correlated with exam and essay performance whereas (Heaven, Ciarrochia \& Vialle, 2007; O'Connor \& Paunonen, 2007) neuroticism has been found to be a negative predictor of academic performance (Landra, Pullman, \& Allick, 2007) and examination performance (Chamorro-Premuzic \& Furnham, 2003). Academic performance more generally has been associated with agreeableness, conscientiousness and openness to experience (Poropat, 2009). Although the literature has yielded ambiguous results in regard to extraversion (Wolf \& Ackerman, 2005), the relationship between FFM and achievement is relatively well documented (see Poropat, 2009 for a meta-analytic review). Nevertheless, the role of the FFM in student engagement has yet to be studied in depth.

Additionally, previous research has typically examined the role of personality on proxies of engagement such as retention (Moses, et al., 2011), academic performance (Glass, Prichard, Lafortune, \& Schwab, 2013), and learning approaches (Zhang \& Huang, 2001). Support comes from a study by Komarraju and Karau (2005) who reported that the traits of extraversion and openness to experience were related to engagement. Limited research has found a link between agreeableness and engagement

\footnotetext{
${ }^{1}$ Although previous literature has used the terms emotional stability (the positive side of the neuroticism scale) and imagination interchangeably with those of neuroticism and openness respectively, we will only use the former terms.
} 
per se, but this does not appear to have been replicated, possibly due to differences in the operationalisation of engagement (see Caspi, Chajut, Saporta, \& Beyth-Marom, 2006). Interestingly, research suggests that agreeableness may be related to the emotional regard a student has towards studying (Wise, Skues, \& Williams, 2011) (see Furnham, Chamorro-Premuzic \& McDouggall, 2002). Critically, these findings indicate the importance of examining a multidimensional model of engagement. In an effort to enhance our theoretical understanding of the nature of engagement, the present study examines the relationship between personality and a multidimensional model of engagement.

\section{Staff and student perceptions of Employability and links with Engagement}

An area of increasing importance within the H.E. sector is that of employability (Cui, 2015; Lau, Hsu, Acosta, \& Hsu, 2014; Yorke, 2004). The increasingly competitive graduate job market has seen an increased emphasis on Personal Development Planning (PDP) to ensure students are equipped with key employability skills (Quality Assurance Agency; QAA, 2009). Although there appears to be a consensus that employability is an integral part of PDP (Bill \& Bowen-Jones, 2010; Bleetman \& Webb, 2008), there is debate over what exactly employability encompasses (see Harvey, 2001; Vanhercke, De Cuyper, Peeters \& De Witte, 2014). Yorke defines employability as "a set of achievements, skills, understandings and personal attributes, that make graduates more likely to gain employment and be successful in their chosen occupations, which benefits themselves, the workforce, the community and the economy" (2004, p. 410). Interestingly, Holmes (2013) goes beyond Yorke's notion of 'skills and attributes' acquisition and makes the distinction between 'possessional' (c.f. skill acquisition; Yorke, 2004), 'positional' (focus on active learning experiences) and 'processual' (the 
learning process extends beyond University) employability (see also Cashian, Clarke \& Richardson, 2015; Hinchcliffe \& Jolly, 2011).

Highly relevant for present purposes, research has shown that there is a lack of engagement with the concept of employability (Betts \& Calabro, 2005; Milner, 2013; Rothwell, Herbert, \& Rothwell, 2008). From a teaching and learning perspective, student (e.g., Gaitán, 2012) and staff (e.g., Powell, 2010) perceptions of employability have been shown to be important. Research suggests that employability/PDP are perceived as both useful (Powell, 2010) and negative by academic staff; the latter view including concerns about the pedagogic value being 'outside' academics' role (Clegg \& Bradley, 2006). There also appears to be tension between the importance of employability/PDP for graduate recruitment possibilities and the time academics have to deliver such activities. Furthermore, there is a strong correlation between staff and student attitudes towards PDP/employability (e.g. Brennan \& Shah, 2003; Cosh, 2008, QAA, 2009), hence, these perceptions are crucial and warrant further exploration.

This study further investigates a less well-researched area: to what extent undergraduate students are engaged with the concept of employability, and how this may relate to staff perceptions of employability. Therefore, in order for the teaching of employability to be effective it is necessary to examine student and staff attitudes towards employability, representing the second objective of this study. Student attitudes will also be compared to their Big-5 personality traits to assess the potentially important role of individual differences, within employability initiatives.

In summary, the present study has two objectives (i) to explore the role of Big-5 personality traits on engagement of students and (ii) to contrast staff and student attitudes towards employability. As research has found differences in engagement and 
attitudes to employability depending on the year of study (Tymon, 2013) two time points were examined: beginning of Year one (T1) and the end of Year one (T2). Accordingly, we expect to find the following:

- An improvement in students' engagement, their understanding of and attitudes towards employability between $\mathrm{T} 1$ and $\mathrm{T} 2(H 1)$

- A positive correlation between attitudes towards employability and student engagement, as well as between staff and student attitudes towards employability $(H 2)$

- A positive relation between Agreeableness and emotional engagement (H3)

- A positive relation between both Conscientiousness and imagination and each of emotional and cognitive engagement $(\mathrm{H} 4)$

\section{Methodology}

\section{Participants}

One hundred and seventeen first year Psychology undergraduate students ${ }^{2}$ (age $M=$ $18.97, S D=2.83)$ and 35 teaching staff $(M=44.55$ years, $\mathrm{SD}=9.5)$ from a post-92 UK university participated. Out of these, 79 students (72\%) took part at T1. At T2, only 38 participated with an attrition rate ${ }^{3}$ of $52 \%$. This is similar to prior attrition rates (Welch

\footnotetext{
${ }^{2}$ From a total requested of 150 students, thereby a response rate of $78 \%$. With a $95 \%$ confidence interval, this gives a sample error rate of $4.3 \%$, suggesting responses were representative of the cohort.

${ }^{3}$ Given the attrition rate, the Big-5 scores of participants who responded again at Time 2 were compared with the personality scores from those who participated at Time $1 \mathrm{only}$. None of
} 
\& Barlau, 2013). All students belonged to the same cohort of undergraduates. Staff members were recruited from different departments of the university running similar employability programmes (Business, Psychology, and Computing). Ethical approval was obtained from the university.

Students took part by completing an online questionnaire at two occasions; (at T1 \& T2. Staff participated once by completing a short paper-based questionnaire about their involvement and attitude towards employability related aspects of the degree.

\section{Measures}

Engagement versus Disaffection with Learning.

The behavioural and affective engagement measure was adapted from Mazer's (2012) “Cognitive Engagement Scale” (CES) and Skinner et al.'s (2008) "Engagement versus Disaffection with Learning Scale" (EvDLS). A number of scale items were adapted from both scales to make them more relevant in the current context (Appendix A). Participants responded to the 18 items using a 7-point Likert scale. Five items measured Behavioural Engagement; 4 measured Emotional Engagement and 9 measured Cognitive Engagement. Good internal consistency has been reported for Skinner's EvDLS ( $\alpha=.81$; Skinner \& Belmont, 1993) and strong construct validity has been reported for both the EvDLS (Fredricks \& McColskey, 2012; Skinner et al., 2008) and the CES (Mazer, 2012; 2013).

Students' understanding of employability. To measure students' understanding of employability, a 23-item measure was used with a 7-point Likert scale (Appendix B). These were based primarily on the Personal Development Planning Questionnaire

the comparisons reached statistical significance, all $p>.05$, suggesting that the data from $\mathrm{T} 1$ $\& \mathrm{~T} 2$ can be reasonably compared. 
(PDP-Q; Micklewright, 2009), though the wording was changed to reflect the current study's emphasis on employability. Twelve questions were reverse scored. According to Micklewright (2009) the initial PDP-Q questionnaire consisted of 51 items, and an abbreviated version of the PDP-Q was subsequently developed through factor analysis. The questionnaire's construct validity was measured using a Correlation between the questionnaire's total score and the number of Personal Development Programme's external measure (e-portfolio actions) performed over a six-month period. Micklewright reported a positive correlation $(r=.333, d f=39, p<0.05)$ indicating moderate validity (Micklewright, 2009).

Big-5 Personality. To measure personality the 50-item Big-5 International Personality Item Pool (IPIP) was used (Goldberg, 1999; Goldberg, 2001), requiring a response on a 7-point Likert scale, (Appendix C). Ten items measured each of the Big-5 traits; Extraversion, Agreeableness, Conscientiousness, Openness, and, Neuroticism. The IPIP relates strongly to major dimensions of personality and has shown good internal consistency (Gow, Whiteman, Pattie \& Deary, 2005). Each factor has shown a mean internal consistency of 0.84 (see Table 2).

Staff and Student Attitudes to Employability. A 15-item questionnaire (Appendix D) was constructed to examine the level of correspondence between student and staff perceptions of employability elements embedded in the curriculum and required responding on a 7-point Likert scale. In line with Hinkin's (1998) guidance on questionnaire development, item generation was informed by previous research (Yorke, 2004; Rothwell et al., 2008, Powell, 2010 \& Micklewright, 2009). The questionnaire was concerned with two main areas of employability; (i) the value and the relevance of the employability element in students' future job prospects; and (ii) students and staff 
involvement in employability programme. The same 15 questions were used for both groups, however, the staff version was slightly modified to suit the group and had 3 additional questions. The students $(n=79)$ responded both at T1 and T2, staff responded only once at $\mathrm{T} 1$. The three additional questions in the staff questionnaire enquired about their involvement, perceived knowledge, time consumed and the departmental support in delivering employability elements of the curriculum, as these were deemed key to understanding their attitudes towards employability. Eight questions were reverse scored on both versions.

\section{Procedure}

The data were collected using Bristol Online Surveys (BOS), and student participants were either rewarded with two research credits for completing both T1 and T2 questionnaires or entered into a prize draw for $£ 20$ Amazon book voucher. Recruitment was through the departmental online research participation scheme (SONA). The staff version of the attitude questionnaire was paper based and distributed among academics at different participating departments. No incentive was offered.

\section{Results}

\section{Student engagement}

BOS does not allow for a two-part questionnaire to be created. Therefore, to be able to link the two parts with each other anonymously, participants were asked to enter their own memorable word ${ }^{4}$ at $\mathrm{T} 1$, and to use it at $\mathrm{T} 2$ to enter and complete the second part.

\footnotetext{
${ }^{4}$ However, it should be noted that out of the 38 participants, only $58 \%$ (22 participants) accurately recalled their memorable words at $\mathrm{T} 2$. Therefore the univariate analyses described in Table 2 have a sample size of 22 .
} 
The internal reliabilities (Cronbach's $\alpha$ ) for the scales were all satisfactory at T1 and T2 (Table 1).

From $\mathrm{T} 1$ to $\mathrm{T} 2$, the general engagement and its subscales of cognitive, behavioural and emotional engagement, all showed a decline (Table 1). These results suggest that general engagement and engagement sub-scales (cognitive, behavioural and emotional engagement) were significantly lower at $\mathrm{T} 2$ compared with $\mathrm{T} 1$. Compared to the range of possible scores, students scored marginally lower on emotional engagement than on cognitive and behavioural engagement at T1. At T2, they scored relatively higher on behavioural engagement than cognitive engagement, and lowest on emotional engagement.

These findings opposed the first hypothesis for the study that engagement would increase over time.

Table 1. Students engagement scores measured at the beginning of the academic year (T1) and measured again after 4 months (T2)

\begin{tabular}{|c|c|c|c|c|c|c|}
\hline \multirow[b]{2}{*}{ Scale } & \multicolumn{2}{|c|}{$\mathrm{T} 1(\mathrm{n}=79)$} & \multicolumn{2}{|c|}{$\mathrm{T} 2(\mathrm{n}=22)$} & \multirow[b]{2}{*}{$\mathrm{R}$} & \multirow[b]{2}{*}{$\mathrm{t}$} \\
\hline & Mean (SD) & $\alpha$ & Mean (SD) & $\alpha$ & & \\
\hline $\begin{array}{l}\text { General } \\
\text { Engagement }\end{array}$ & $94.08(17.25)$ & 0.94 & $79.95(25.66)$ & 0.95 & $.649 * *$ & $-3.18 * *$ \\
\hline $\begin{array}{l}\text { Cognitive } \\
\text { Engagement }\end{array}$ & $46.48(9.40)$ & 0.88 & $39.27(13.39)$ & 0.90 & $.624 * *$ & $-3.5^{* *}$ \\
\hline $\begin{array}{l}\text { Behavioural } \\
\text { Engagement }\end{array}$ & $27.09(4.88)$ & 0.80 & $23.64(6.61)$ & 0.84 & $.712 * *$ & $-2.71 *$ \\
\hline $\begin{array}{l}\text { Emotional } \\
\text { Engagement }\end{array}$ & $20.52(4.66)$ & 0.79 & $17.05(6.68)$ & 0.88 & $.498 * *$ & $-2.36^{*}$ \\
\hline $\begin{array}{l}\text { Understanding } \\
\text { of employability }\end{array}$ & $110.09(15.33)$ & 0.86 & $104.14(16.93)$ & 0.87 & $.777 * *$ & -1.36 \\
\hline $\begin{array}{l}\text { Attitude towards } \\
\text { employability }\end{array}$ & $74.29(11.83)$ & 0.84 & $73.45(14.25)$ & 0.87 & $.459 * *$ & 0.80 \\
\hline
\end{tabular}




\section{Student Big-5 personality trait}

Table 2 shows the scores for each trait. All reliability $(\alpha)$ coefficients were adequate.

Table 2: Big-5 traits scores for students

\begin{tabular}{lccc} 
Big-5 Trait & Mean (SD) & Range & Reliability $(\alpha)$ \\
\hline Extraversion & $41.94(11.91)$ & $12-65$ & 0.91 \\
Agreeableness & $56.24(7.75)$ & $34-69$ & 0.78 \\
Conscientiousness & $45.58(10.37)$ & $20-67$ & 0.86 \\
Emotional Stability & $35.19(12.12)$ & $10-67$ & 0.89 \\
Imagination & $48.48(6.34)$ & $28-60$ & 0.61 \\
\hline
\end{tabular}

\section{Student understanding of employability}

Students' understanding of and attitude to employability were measured at T1 and T2.

Reliabilities were satisfactory at T1 and T2 (Table 1). Their understanding of and attitudes to employability remained unchanged from T1 through $\mathrm{T} 2$ (both $p \mathrm{~s}>.05$; Table 1), contrary to $\mathrm{H} 1$.

\section{Correspondence between staff and student attitudes towards employability programme}

To investigate whether there would be a positive correlation between attitudes towards employability (H2), scores on attitudes to employability were compared between the staff $^{5}$ and student groups at T1 and T2 using an independent samples t-test. For this comparison, staff only questions were removed from that version. This compares the distribution of the scores between the staff and student groups, and showed no significant difference $(t(112)=-0.753, p=0.45)$, suggesting that their attitude scores were correlated. The mean scores for staff and students were 73.47 and 74.29

\footnotetext{
${ }^{5}$ The internal reliability for the full staff version was 0.86 , and for the reduced version 0.85 .
} 
respectively, where the highest possible score was 115 , suggesting a generally positive attitude towards employability in both samples. Examination of individual question responses for the staff questionnaire showed lower scores for questions on training and support for the delivery of employability, and on the time available to engage and develop the employability skills of students.

Furthermore, the association between understanding of and attitudes to employability, multidimensional engagement, and Big-5 traits were calculated, shown in Table 3. General engagement, engagement subscales, understanding of, and attitudes to, employability were all significantly correlated with one another, supporting H2.

Emotional engagement was significantly correlated with agreeableness, supporting H3, and was also correlated with conscientiousness and imagination (all $p \mathrm{~s}<.001$ ). Engagement, together with the sub-scales of cognitive and behavioural engagement, were significantly correlated with agreeableness, conscientiousness and imagination (all $p$ s $<.001$ ). This provided partial support for $\mathrm{H} 4$ (conscientiousness and imagination will be positively related to emotional and cognitive engagement). Behavioural engagement was additionally correlated with extraversion $(p<.05)$. As shown in Table 3 , understanding of employability was significantly correlated with agreeableness and conscientiousness $(p<.05)$. Attitude to employability was significantly correlated with agreeableness, emotional stability $(p<.05)$ and conscientiousness $(p<.001)$.

Table 3. Correlations between general engagement, engagement sub-scales, understanding of employability, attitudes to employability and personality traits in the $\mathrm{T} 1$ group. 


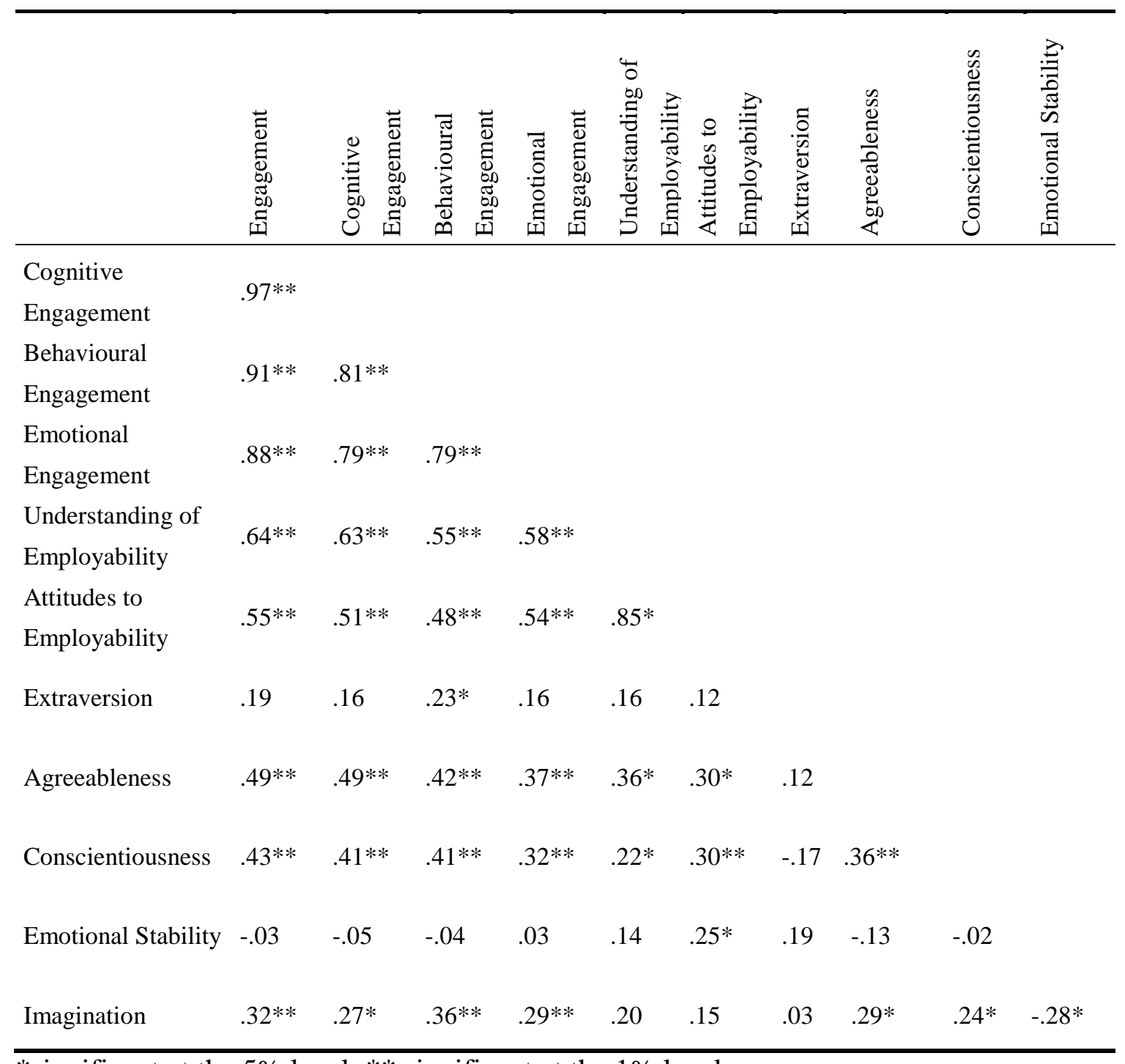

*significant at the 5\% level; ** significant at the $1 \%$ level

\section{Predicting engagement, understanding of- and attitude to employability through}

\section{Big-5 traits}

To explore whether the Big-5 personality traits are significant predictors of both engagement (general, cognitive, behavioural and emotional), and understanding of and attitude to employability, six multiple regression analyses were conducted (Table 1, Appendix E). 
Predicting general engagement through personality traits

Personality traits produced a significant model that accounted for a reasonable degree of variance in engagement: $F(5,73)=8.74, p<0.01, R^{2}=0.37$. Increases in extraversion $(\beta=0.20, p<0.05)$, agreeableness $(\beta=0.31, p<0.01)$ and conscientiousness $(\beta=0.31$, $p<0.01)$ were associated with increased general engagement. Neither emotional stability $(\beta=0.02, p>0.05)$ or imagination $(\beta=0.16, p>0.05)$ predicted engagement. Approximately a third of the variance in general engagement was explained by personality partially supporting $\mathrm{H} 4$.

\section{Predicting cognitive engagement through personality traits}

Personality traits produced a significant model that accounted for a reasonable degree of variance in cognitive engagement: $F(5,73)=7.31, p<0.01, R^{2}=0.33$. Increases in agreeableness $(\beta=0.34, p<0.01)$ and conscientiousness $(\beta=0.29, p<0.01)$ were both associated with increased cognitive engagement. Neither extraversion $(\beta=0.17, p>$ $0.05)$, emotional stability $(\beta=-0.01, p>0.05)$ or imagination $(\beta=0.10, p>0.05)$ predicted cognitive engagement. Personality explained a third of the variance in cognitive engagement.

\section{Predicting behavioural engagement through personality traits}

Personality traits produced a significant model that accounted for a reasonable degree of variance in behavioural engagement: $F(5,73)=8.19, p<0.01, R^{2}=0.36$. Increases in extraversion $(\beta=0.25, p<0.05)$, agreeableness $(\beta=0.22, p<0.01)$, conscientiousness $(\beta=0.32, p<0.01)$ and imagination $(\beta=0.21, p<0.05)$ were all associated with increased behavioural engagement. Emotional stability $(\beta=0.01, p>$ 
0.05) did not predict behavioural engagement. Behavioural engagement was again well explained by personality, with $30 \%$ variance being explained.

\section{Predicting emotional engagement through personality traits}

Personality traits produced a significant model that accounted for a reasonable degree of variance in emotional engagement: $F(5,73)=4.50, p<0.05, R^{2}=0.24$. However, neither extraversion $(\beta=0.15, p>0.05)$, agreeableness $(\beta=0.23, p>0.05)$, conscientiousness $(\beta=0.22, p>0.05)$, emotional stability $(\beta=0.09, p>0.05)$ or imagination $(\beta=0.11, p>0.05)$ individually predicted emotional engagement. Emotional engagement was only predicted by agreeableness (H3), and this accounted for approximately $18 \%$ of the variance.

\section{Predicting understanding of employability through personality traits}

Personality traits produced a significant model that accounted for a reasonable degree of variance in understanding of employability: $F(5,73)=3.66, p<0.01, R^{2}=0.20$. An increase in agreeableness $(\beta=0.30, p<0.05)$ was associated with increased attitudes to and understanding of employability. Neither extraversion $(\beta=0.10 p>0.05)$, conscientiousness $(\beta=0.15, p>0.05)$ or emotional stability $(\beta=0.20, p>0.05)$ predicted understanding of employability. Counter to H5, imagination $(\beta=0.15, p>$ 0.05 ) did not significantly predict understanding of employability. Approximately $15 \%$ of the variance was explained by personality, with agreeableness being the only significant predictor.

\section{Students' Attitudes towards employability}

Personality traits produced a significant model that accounted for a reasonable degree of variance in attitudes to employability: $F(5,73)=4.27, p<0.01, R^{2}=0.23$. 
An increase in emotional stability $(\beta=0.30, p<0.01)$ was associated with increased attitudes to employability. Neither extraversion $(\beta=0.07 p>0.05)$, agreeableness $(\beta=$ $0.22, p>0.05)$, conscientiousness $(\beta=0.21, p>0.05)$ or imagination $(\beta=0.12, p>$ $0.05)$ predicted attitudes to employability. Seventeen percent of the variance was explained by personality, specifically by emotional stability.

\section{General Discussion}

The role of personality on academic achievement is well documented (e.g., Farsides \& Woodfield, 2006); however, the influence of personality traits on student engagement, particularly multidimensional models of engagement, is less understood. A major objective of the present study was to explore whether Big-5 personality traits could predict students' general, cognitive, emotional and behavioural engagement. Given the importance of student engagement for academic success (Newmann, Wehlage, \& Lamborn, 1992; Marks, 2000) a second objective was to investigate whether student engagement changed over time and how student engagement related to staff engagement. Given the links between employability and student engagement (Senior, Reddy \& Senior, 2014; Zepke \& Leach, 2010) the study also explored staff and student attitudes toward employability and their relationship.

\section{Key Variables Influencing Student Engagement and Attitudes towards Employability}

The role of personality on student engagement was examined and, as predicted, the trait of conscientiousness was an important factor. Specifically, conscientiousness was a significant predictor in all aspects of engagement except emotional engagement. These 
findings corroborate a wealth of research on the importance of this trait in educational (Furnham, Chamorro-Premuzic \& McDougall, 2002; Heaven, Ciarrochi \& Vialle, 2007; O'Connor \& Paunonen, 2007) and employment (Barrick, Mount, \& Strauss, 1993) settings. In particular, conscientiousness is consistently and positively associated with assessment performance, likely due to the hard-working and motivated nature of this trait (Heaven, Ciarrochi \& Vialle, 2007; O'Connor \& Paunonen, 2007). The results also converge with previous research by Kim, Shin, and Swanger (2009), who found a positive relationship between conscientiousness and academic engagement. In line with trait definitions of conscientiousness, individuals high in this trait tend to be 'achievement orientated', 'think before they act' and 'plan' - all of which support the present links with cognitive engagement. Interestingly, this trait also encompasses behavioural facets such as 'goal-directed' behaviour, 'purposefulness' and 'prioritising tasks' (John \& Srivastava, 1999), hence supporting the relationship with behavioural engagement. The emergence of a non- significant relation between conscientiousness and emotional engagement is also in line with trait definitions and can, to some extent, begin to develop our understanding of the nature of engagement and its key predictors. Agreeableness was found to be a reliable predictor of general engagement, cognitive, emotional, and behavioural engagement (all $p$ s $<.05$ ). Given that agreeableness encompasses facets such as altruism, compliance, and trustworthiness (John \& Srivastava, 1999), the current findings suggest that being engaged relates to 'trusting' in the educational process and caring about it. Those high in agreeableness also have an optimistic view of human nature (Costa \& McCrae, 1992; John \& Srivastava, 1999) and may be positive about the educational experience. Support for the role of agreeableness on engagement comes from research by Furnham et al. (2002) who comment that agreeableness may be related to social and emotional aspects of 
engagement. However limited research has found this link between agreeableness and engagement per se, which may be due to differences in the way that engagement has been operationalised (see Caspi et al., 2006). The finding that agreeableness significantly predicted all aspects of engagement is interesting and warrants further examination.

Although extraversion was not predicted to correlate with engagement, analyses revealed that this trait significantly predicted general and behavioural engagement. While the literature has yielded ambiguous results for the trait of extraversion (Wolf \& Ackerman, 2005) this finding makes intuitive sense as extraversion is a behaviourally oriented trait (Costa \& McCrae, 1992). This finding further converges with trait definitions as extraverts tend to be optimistic, sociable and assertive and prefer groups (Costa \& McCrae, 1992; John \& Srivastava, 1999). Extraverted individuals are also more likely to experience vigour; one of the core dimensions of work engagement (Brief \& Weiss, 2002). More direct support comes from a study by Komarraju and Karau (2005) who reported that the trait of extraversion is linked to engagement.

Perhaps surprisingly, the hypothesised relation between intellect and engagement was not supported. This trait concerns openness to new ideas, creativity, and capacity for abstract thought and would seem an ideal predictor of engagement, albeit limited research has found this (see Poropat, 2009). It should be noted that the majority of research has examined the role of intellect with achievement outcomes (Paunonen \& Ashton, 2001) and intelligence (Ashton, Lee, Vernon, \& Jang, 2000). The trait itself has been shown to be a correlate of intelligence (Harris, 2004), and out of all the Big- 5 traits has been suggested to be the most controversial and inconsistent (see McCrae, 1993-1994). It will be interesting to see if future research can replicate the present findings for intellect with behavioural, emotional and cognitive engagement. 
Taken together, the results for the Big-5 traits and engagement are interesting and encouraging and add to the growing literature surrounding the theoretical basis of the construct of engagement (Zaidi et al., 2013). Clearly, there is still work to be done on the operationalisation of engagement but reliable predictors of engagement can begin to develop our understanding of what it means to 'be engaged' and what qualities can increase the likelihood of engagement. Results suggest that agreeableness and conscientiousness are particularly important predictors of engagement. The pattern of findings are also encouraging in terms of integrating a variety of assessment types and practises into H.E. so that different personalities have opportunities to be cognitively, behaviourally and emotionally engaged. This supports Kuh et al's. (2008) suggestion for activities to be tailored to the individual for maximum engagement.

\section{Does Student Engagement change over time?}

A major objective of the present study was to examine whether engagement changed over time. It should be noted that due to the attrition rate from $\mathrm{T} 1$ and $\mathrm{T} 2$, the linking of participant data through a memorable word or number was shown to be problematic, resulting in a small usable sample size at $\mathrm{T} 2$. Nevertheless, results showed that student engagement decreased from T1 to T2. Although counter to predictions, this finding makes intuitive sense as students arguably enter H.E. motivated and keen to succeed with unrealistic expectations (King \& Walsh, 1972; see also Gerdes \& Mallinckrodt, 1994), often termed the freshman myth, which may be difficult to maintain. Although further research is needed, this tentative suggestion has been supported (see Harvey, 2001; Vanhercke, et al., 2014). It is plausible that the decrease in engagement is due to differences in students' perceptions and H.E.'s definitions of employability. Interestingly, student and staff attitudes towards employability were significantly 
correlated, implying scope to improve both. Indeed, there is a growing literature on the importance of staff attitudes to engagement in terms of its impact on student perceptions (Powell, 2010). Yet at the same time, staff feel overwhelmed and overburdened and some have questioned the importance of PDP in H.E. (Brennan \& Shah, 2003; Cosh, 2008). Taken together, these highlight important areas for future investigation.

A strength of the current research was the focus on a multidimensional model of engagement; however, it is important to note that our study focused solely on psychological predictors of engagement (i.e personality and attitudes) but not on sociological or contextual aspects (c.f. Lawson \& Lawson, 2013; Eccles \& Wang, 2012; Gasper, DeLuca, \& Estacion, 2012; Janosz, 2012). Therefore, in addition to the need for replication of the current findings, future studies should explore these broader aspects of engagement which may provide a more nuanced understanding.

\section{How similar are Students and staff attitudes?}

Contrary to previous findings reported by Tymon (2013), suggesting a limited alignment between the views of students and staff on the importance of employability, the current study revealed a high correspondence. In line with Brennan and Shah (2003; Cosh, 2008), both groups perceived employability as being valuable and important in students' future. However, the staff attitudes also reflected a perceived need for training, and a perceived lack of time with regards to involvement and development of the employability skills of students.

A successful employability programme impacts on different stakeholders. Future employers, universities, as well as students benefit from broadening the employability elements embedded in any degree programme. Students' employment outcome is one of the major indicators designed to measure the performance of 
universities by a variety of HE league tables as well as the government. At the same time, the current labour market needs students who have more than a degree on their $\mathrm{CV}$ and are flexible to changes in the market. Furthermore, employability encompasses more complex processes than completing a PDP embedded in the curriculum and acquiring generic skills during the first year of a degree.

The mandatory inclusion of employability has been subject to debate (Pan \& Lee, 2011). Through the inclusion of employability elements and PDP in the curriculum, students, probably for the first time, become aware that they need more than a degree to succeed in their career. This "jolt" of awareness might explain the reason for the participants in this study showing lesser opinions towards employability at T2 compared to T1. The results may indicate the necessity of capitalising on this "awareness" and augmenting employability and PDP elements in the curriculum. Employability skills and PDP programmes will equip them with such skills and engage them in their own career building process (c.f. Bridgestock, 2009).

\section{A word of caution}

One factor that might limit the study's generalisability is that the sample was drawn from a North West UK university, which in terms of student cohort may be qualitatively different from other universities. According to the "Communities and Local Government report on the English Indices of deprivation" (2007) North West of England is among the regions with highest deprivation indices and lowest employment (Office of National Statistics, 2012). Therefore generalisability may be limited to similar cohorts/regions, though programs focusing on employability are nowadays becoming ubiquitous. Different aspects of employability, particularly positional and processual, could also be assessed (c.f. Yorke, 2004). 
Another limitation of the current research is the attrition. Although the finding that engagement over time decreases is in line with numerous studies (see Trowler, 2010, for a review) further research is needed to determine whether the current findings can be replicated. One factor that might have affected the results was group differences between those students who remembered their memorable phrase, and therefore allowing their data from $\mathrm{T} 1$ and $\mathrm{T} 2$ to be linked, and those students who did not. To rule this out, personality trait and other questionnaire scores of both groups were compared, revealing no significant differences. Future research could adopt a more longitudinal perspective, following students from the first semester until their graduation and tracking attitudes, engagement and academic performance.

\section{Conclusion}

Taken together, the findings suggest that there are important individual differences which relate in different ways to students' general, emotional, behavioural and cognitive engagement in learning. Focusing on multidimensional models of engagement appears to offer a promising approach to advancing our theoretical understanding of the nature of student engagement.

\section{References}

Ashton, M. C., Lee, K., Vernon, P. A., \& Jang, K. L. (2000). Fluid intelligence, crystallized intelligence, and the Openness/Intellect factor. Journal of Research in Personality, 34(2), 198-207. doi:10.1006/jrpe.1999.2276

Astin, A. W. (1993). What matters in college: Four critical years revisited. San Francisco: Jossey-Bass. 
Barrick, M. R., Mount, M. K., \& Strauss, J. P. (1993). Conscientiousness and performance of sales representatives: Test of the mediating effects of goal setting. Journal of Applied Psychology, 78(5), 715-722. doi:10.1037/0021-9010.78.5.715

Betts, M., \& Calabro, P. 2005. Enhancing student employability: Higher Education and Workforce Development. Ninth Quality in Higher Education International Seminar, Birmingham.

Bill, K., \& Bowen-Jones, W. (2010). Enhancing Enterprise, Entrepreneurship and Employability through PDP: Employability Case Study. Hospitality, Leisure, Sport and Tourism Network.

Bleetman, J., \& Webb, L. (2008). "Enhancing employability through professional experience and personal development planning (PDP)". The International Journal of Learning 15(10): 191-196.

Bok, D. (2006). Our underachieving colleges: a candid look at how much students learn and why they should be learning more, Princeton, New Jersey: Princeton University Press

Brennan, J. \& Shah, T. (2003). Access to what? Converting education opportunity into employment opportunity. Centre for Higher Education Research and Information, London, UK.

Brief, A. P., \& Weiss, H. M. (2002). Organizational behavior: Affect in the workplace. Annual Review of Psychology, 53, 279-307

BOS: Bristol Online Survey Tool. www.survey.bris.ac.uk

Cashian, P., Clarke, J., \& Richardson, M. (2015). Perspectives on: Employability Is it Time to Move the Employability Debate on?. Chartered Association of Business Schools: Publications, 1-9.

Caspi, A., Chajut, E. Saporta, K., \& Beyth-Marom, R. (2006). "The influence of personality on social participation in learning environments". Learning and Individual Differences 16(2): 129-144.

Chamorro-Premuzic, T., \& Furnham, A. (2003). Personality predicts academic performance: Evidence from two longitudinal university samples. Journal of Research in Personality, 37(4), 319-338. doi:10.1016/S0092-6566(02)00578-0

Chamorro-Premuzic, T., \& Furnham, A. (2008). "Personality, intelligence and approaches to learning as predictors of academic performance". Personality and individual differences 44(7): 1596-1603.

Cui, S. (2015). Research on the Improving Path of College Student Employability from Social Practice Perspective. Journal of Applied Science and Engineering Innovation Vol, 2(3), 81-83.

Clegg, S., \&. Bradley, S. (2006). "Models of Personal Development Planning: practice a processes". British Educational Research Journal 32(1): 57-76.

Cosh, J. (2008). Outcomes of a personal development planning evaluation project at Anglia Ruskin University. PDP and ePortfolio UK Newsletter, 14.

Costa, P. T., \& McCrae, R.R. (1992). "Four ways five factors are basic". Personality and individual differences 13(6): 653-665.

Digman, J. M. (1990). "Personality structure: "Emergence of the five-factor model". Annual review of psychology 41(1): 417-440.

Eccles, J., \& Wang, M. T. (2012). Part I commentary: So what is student engagement anyway? In S. L. Christenson, A. L. Reschly, \& C. Wylie (Eds.), Handbook of research on student engagement (pp. 133-145). New York, NY: Springer. 
Farsides, T., \& Woodfield, R. (2006). "Individual and gender differences in 'good' and 'first class' undergraduate degree performance". British Journal of Psychology 98(3): 467-483

Fowler, P.R. \& Boylan, H.R. (2010). Increasing Student Success and Retention: A Multidimensional Approach. Journal of Developmental Education, 34 (2), pp 1-10.

Fredricks, J. A., Blumenfeld, P. C., \& Paris, A. H. (2004). School engagement: Potential of the concept, state of the evidence. Review of Educational Research, 74(1), 59-109. doi:10.3102/00346543074001059

Fredricks, J.A \& McColskey, W. (2012). The Measurement of Student Engagement: A Comparative Analysis of Various Methods and Student Self-report Instruments. In S.L. Christenson et al. (eds.), Christenson, S., Reschly, A. L., \& Wylie, C. (2012). Handbook of research on student engagement. New York: Springer. 763-782.

Furnham, A., Chamorro-Premuzic, T., \& McDougall, F. (2002). Personality, cognitive ability, and beliefs about intelligence as predictors of academic performance. Learning and Individual Differences, 14(1), 47-64.

Furnham, A., Monsen, J. \& Ahmetoglu, G. (2009). "Typical intellectual engagement, Big Five personality traits, approaches to learning and cognitive ability predictors of academic performance". British Journal of Educational Psychology, 79(4): 769-782.

Gaitán, A. (2012). "Understanding Students' Experiences of e-PDP and the Factors that Shape their Attitudes". International Journal of ePortfolio, 2(1): 29-38.

Gerdes, H., \& Mallinckrodt, B. (1994). Emotional, social, and academic adjustment of college students: A longitudinal study of retention. Journal of Counseling \& Development, 72(3), 281-288. doi:10.1002/j.1556-6676.1994.tb00935.x

Glass, R., Prichard, J, Lafortune, A. \& Schwab, N. (2013). "The influence of personality and facebook use on student academic performance". Issues in Information Systems, 14(2): 119-126.

Goldberg, L. R. (1999). "A broad-bandwidth, public-domain, personality inventory measuring the lowerlevel facets of several Five-Factor models". In Personality psychology in Europe Vol. 7. Edited by I.J. Mervielde, J. Deary, F. de Fruyt, and F. Ostendorf . 7-28. Tilburg: Tilburg University Press.

Goldberg, L. R. (2001). International Personality Item Pool. http://ipip.ori.org/

Gow, A. J., Whiteman, M.C., Pattie, A \& Deary, I.J. (2005). "Goldberg's 'IPIP' Big-Five factor markers: Internal consistency and concurrent validation in Scotland". Personality and Individual Differences 392: 317-329.

Gasper, J., DeLuca, S., \& Estacion, A. (2012). Switching schools: Revisiting the relationship between school mobility and high school dropout. American Educational Research Journal, 49(3), 487519. doi:10.3102/0002831211415250

Harper, S. R., \& Quaye, S. J. (Eds.). (2009). Student engagement in higher education, theoretical perspectives and practical approaches for diverse populations. New York, NY: Routledge.

Harris, A. J. (2004). Measured intelligence, achievement, openness to experience, and creativity. Personality and Individual Differences, 36(4), 913-929. doi:10.1016/S0191-8869(03)00161-2

Harvey, L., (2001), 'Defining and measuring employability', Quality in Higher Education, 7(2). 
Heaven, P. C. L., Ciarrochi, J., \& Vialle, W. (2007). Conscientiousness and eysenckian psychoticism as predictors of school grades: A one-year longitudinal study. Personality and Individual Differences, 42(3), 535-546. doi:10.1016/j.paid.2006.07.028

Hinchliffe, G. W., \& Jolly, A. (2011). Graduate identity and employability. British Educational Research Journal, 37(4), 563-584. doi:10.1080/01411926.2010.482200

Hinkin, T. R. (1998). A brief tutorial on the development of measures for use in survey questionnaires. Organizational research methods, 1(1), 104-121.

Holmes, L. (2013). Competing perspectives on graduate employability: Possession, position or process? Studies in Higher Education, 38(4), 538-554. doi: 10.1080/03075079.2011.587140

Janosz, M. (2012). Part IV Commentary: Outcomes of engagement and engagement as an outcome: Some consensus, divergences, and unanswered questions. In S. L. Christenson, A. L. Reschly, \& C. Wylie (Eds.), Handbook of research on student engagement (pp. 695-703). New York, NY: Springer.

John, O. P., \& Srivastava, S. (1999). The Big Five trait taxonomy: History, measurement, and theoretical perspectives. In L. A. Pervin, \& O. P. John (Eds.), Handbook of personality: Theory and research (pp. 102-138). New York: Guilford Press

Kim, H. J., Shin, K.H. \& Swanger, N. (2009). "Burnout and engagement: A comparative analysis using the Big Five personality dimensions". International Journal of Hospitality Management 28(1): 96-104.

King, H., \& Walsh, W. (1972). Change in environmental expectations and perceptions. Journal of College Student Personnel. 13, 331-340.

Kuh, G.D. (2001). Assessing what really matters to student learning: Inside the National Survey of Student Engagement. Change, 33(3), 10-17, 66

Kuh, G. D. (2003). What We're Learning About Student Engagement From NSSE: Benchmarks for Effective Educational Practices. Change, 35 (2): 24-32

Kuh, G.D., Cruce, T.M., Shoup, R., Kinzie, J. \& Gonyea, R.M. (2008). Unmasking the Effects of Student Engagement on First-Year College Grades and Persistence. The Journal of Higher Education, 79 (5), $540-563$

Komarraju, M \&. Karau, S.J. (2005). "The relationship between the Big Five personality traits and academic motivation". Personality and Individual Differences 39: 557-567

Landra, K., Pullmann, H \& Allick, A. (2007). "Personality and intelligence as predictors of academic achievement". Personality and Individual Differences, 42: 441-451

Lau, H. H., Hsu, H. Y., Acosta, S., \& Hsu, T. L. (2014). Impact of participation in extra-curricular activities during college on graduate employability: an empirical study of graduates of Taiwanese business schools. Educational Studies, 40(1), 26-47.

Lawson, M. A., \& Lawson, H. A. (2013). New conceptual frameworks for student engagement research, policy, and practice. Review of Educational Research, 83(3), 432-479.

doi:10.3102/0034654313480891 
Lounsbury, J.W., Hutchens, T. \& Loveland, J.M. (2005). "An investigation of Big Five personality traits and career decidedness among early and middle adolescents". Journal of Career Assessment 13(1): 25-39.

McCrae, R.R. (1993-1994) Openness to experience as a basic dimension of personality. Imagination, Cognition, and Personality, 13, 39-55

McCrae, R. R., \& Costa, P. T. (1997). Personality trait structure as a human universal. American Psychologist, 52(5), 509-516. doi:10.1037/0003-066X.52.5.509

Marks, H. M. (2000). "Student engagement in instructional activity: Patterns in the elementary, middle, and high school years". American educational research journal 37(1): 153-184.

Maslach, C., Schaufelli, W.B \& Leiter, M.P. (2001). "Job burnout". Annual Review of Psychology 52: 397-422.

Mazer, J. P. (2012). Development and validation of the student interest and engagement scales. Communication Methods and Measures, 6(2), 99-125. doi:10.1080/19312458.2012.679244

Mazer, J. R. (2013). Associations among teacher communication behaviors, student interest, and engagement: A validity test. Communication Education,62(1), 86. doi:10.1080/03634523.2012.731513

Mega, C., Ronconi, L., \& De Beni, R. (2014). "What makes a good student? How emotions, selfregulated learning, and motivation contribute to academic achievement". Journal of Educational Psychology 106(1): 121-131. http://dx.doi.org/10.1037/a0033546

Meyer, D. K., \& Turner, J.C. (2002). "Using instructional discourse analysis to study the scaffolding of student self-regulation. Educational psychologist, 37: 17-25.

Micklewright, D. (2009). "Adherence and Participation Factors in Personal Development Planning". In Enhancing Student Centred Learning in Business and Management, Hospitality, Leisure, Sport and Tourism Network. Edited by J. Buswell and N Beckett. 1-13. Threshold Press Limited: Newbury UK.

Milner, H. R. (2013). "Rethinking achievement gap talk in urban education". Urban Education 48(1): 3-8.

Moses, L., C. Hall, K. Wuensch, K. De Urquidi, P. Kauffmann,W, Swart, and G. Dixon. 2011. "Are math readiness and personality predictive of first-year retention in engineering?" The Journal of Psychology 145: 229-245.

Newmann, F. M., Wehlage, G. G., \& Lamborn, S. L. (1992). The significance and sources of student engagement. In F. M. Newmann, (Ed.), Student Engagement and Achievement in American Secondary Schools (pp. 11-39). New York, Teachers College Press.

O’Connor, M.C. \& Paunonen, S.V. (2007). "Big Five personality predictors of post-secondary academic performance". Personality and Individual Differences 43(5): 971-990.

Ozer, D. J., \& Benet-Martinez, V. 2006. "Personality and the prediction of consequential outcomes". Annu. Rev. Psychol. 57: 401-421. 
Pan, Y \& Lee, L. (2011). Academic Performance and Perceived Employability of Graduate Students in Business and Management - An Analysis of Nationwide Graduate Destination Survey. Procedia - Social and Behavioral Sciences, 25: 91-103.

Paunonen, S. V., \& Ashton, M. C. (2001). Big five predictors of academic achievement. Journal of Research in Personality, 35(1), 78-90. doi:10.1006/jrpe.2000.2309

Pierson, L. H., \& Connell, J.P. (1992). "Effect of grade retention on self-system processes, school engagement, and academic performance". Journal of Educational Psychology 84: 300-307

Poropat, A. E. (2009). "A meta-analysis of the five-factor model of personality and academic performance". Psychological Bulletin 135(2):322-38

Powell, J. (2010). "Useful or just another fad? Staff perceptions of personal development planning". Journal of Learning Development in Higher Education, Special Edition. Research PDP Practice 1-15. Accessed Nov. 2015.

http://www.aldinhe.ac.uk/ojs/index.php?journal=jldhe\&page=article\&op=view\&path\%5B $\% 5 \mathrm{D}=$ $101 \&$ path $\% 5 \mathrm{~B} \% 5 \mathrm{D}=55$

Quality Assurance Agency; QAA, (2009). Personal development planning: guidance for institutional policy and practice in higher education. Accessed online July 2015 at http://www.qaa.ac.uk/en/Publications/Documents/Personal-development-planning-guidance-forinstitutional-policy-and-practice-in-higher-education.pdf.

Rothwell, A., Herbert, I. \& Rothwell, F. (2008). "Self-perceived employability: Construction and initial validation of a scale for university students". Journal of vocational behavior: 73(1), 1-12.

Schaufeli, W.B., Salanova, M., Gonzalez-Roma, V. and Bakker, A.B. (2002). "The measurement of burnout and engagement: A confirmatory factor analytic approach". Journal of Happiness Studies 3: 71-92.

Senior, C., Reddy, P., \& Senior, R. (2014). The relationship between student employability and student engagement: working toward a more unified theory. Frontiers in Psychology, 5 (March) 238. 10.3389/fpsyg.2014.00238

Skinner, E, Furrer, C. Marchand, G. and Kindermann, T. (2008). "Engagement and disaffection in the classroom: Part of a larger motivational dynamic?" Journal of Educational Psychology 100(4): 765-781. http://dx.doi.org/10.1037/a0012840

Skinner, E. A., \& Belmont, M. J. (1993). "Motivation in the classroom: Reciprocal effects of teacher behavior and student engagement across the school year". Journal of educational psychology 85(4): 571-581

The Office for National Statistics (2012). Regional Profiles: Key Statistics - North West, August 2012

Trowler, V. (2010). Student engagement literature review. Lancaster University. Retrieved from: https://www.heacademy.ac.uk/sites/default/files/studentengagementliteraturereview_1.pdf

Tymon, A. (2013). "The student perspective on employability". Studies in Higher Education, 38(6): 841856

Vanhercke, D., De Cuyper, N., Peeters, .E. \& De Witte, H. (2014)."Defining perceived employability: a psychological approach", Personnel Review, 43 (4): 592 - 605 
Welch, W. W. \& Barlau, A. N. (2013). Addressing Survey Nonresponse Issues: Implications for ATE Principal Investigators, Evaluators, and Researchers. Colorado, United States: DECA Project. Retrieved from http://www.colorado.edu/ibs/decaproject/pubs/Survey\%20nonresponse\%20issues\%20Implicatio ns\%20for\%20ATE\%20PIs\%20researchers\%20\%20evaluators.pdf

Wentzel, K. R. (1993). "Does being good make the grade? Social behavior and academic competence in middle school". Journal of Educational Psychology 85(2): 357-364.

Wise, L., Skues, J., \& Williams, B. (2011). Facebook in higher education promotes social but not academic engagement. Proceedings Ascilite 2011 Hobart, 1332-1342. Retrieved form: http://www.ascilite.org/conferences/hobart11/downloads/papers/Wise-full.pdf

Wolf, M. B., \& Ackerman, P. L. (2005). Extraversion and intelligence: A meta-analytic investigation. Personality and Individual Differences, 39(3), 531-542. doi:10.1016/j.paid.2005.02.020

Yorke, M. (2004). "Employability in the undergraduate curriculum: some student perspectives". European Journal of Education 394: 409-427.

Zaidi, N. R., Wajid, R. A., Zaidi, F. B., Zaidi, G. B., \& Zaidi, M. T. (2013). The big five personality traits and their relationship with work engagement among public sector university teachers of Lahore. African Journal of Business Management, 7(15), 1344. doi:10.5897/AJBM12.290

Zepke, N. \& Leach, L. (2010). Improving student engagement: Ten proposals for action. Active Learning in Higher Education, 11 (3), 167 - 177

Zhang, L-F., \& Huang, J.F. (2001). "Thinking styles and the Five-Factor model of personality". European Journal of Personality 15(6): 465-476. 


\section{Appendix A}

\section{Students' Engagement Questionnaire}

1. I listen attentively to the tutor during sessions. (Cognitive engagement)

2. I work as hard as I can in this module. (Behavioural engagement)

3. I am keen to learn about the content within this module. (Emotional engagement)

4. I listen attentively to my classmates' contributions during class discussions. (Cognitive engagement)

5. I attend class regularly. (Cognitive engagement)

6. When in class, I participate in class discussions. (Behavioural engagement)

7. I pay attention in class. (Behavioural engagement)

8. Class discussions and activities interest me. (Emotional engagement)

9. I get involved in class activities. (Emotional engagement)

10. I find this module useful and engaging. (Cognitive engagement)

11. I find it difficult to concentrate in this module. (Behavioural engagement)

12. When in this class I often feel bored. (Emotional engagement)

13. I think about how I can utilise the module material outside of University. (Cognitive engagement)

14. I think about how the module material will benefit me in my future career. (Cognitive engagement)

15. I review my notes outside of sessions. (Cognitive engagement)

16. I complete all assignments and module activities to the best of my ability. (Behavioural Engagement)

17. I talk about the module material with others outside of the module. (Cognitive engagement)

18. I often take it upon myself to read additional material on issues relating to employability and employability skills. (Cognitive engagement) 


\section{Appendix B}

\section{Students' Understanding of employability}

1. I think employability skills classes are an important aspect of University Learning.

2. There are sufficient resources for developing my employability skills at University.

3. I think employability skills developed during University will be beneficial to my future employment.

4. I am NOT really interested in employability skills training/activities since I have mainly come to University to learn my chosen subject.

5. It is worthwhile participating in employability activities as well as academic activities.

6. I am responsible for developing my employability skills at University.

7. I think Employability skills classes should be optional at University.

8. I do NOT think there are many opportunities at University to develop my employability skills.

9. Even if I was busy with other academic activities, I would try to find time for employability related activities at University.

10. Other people might think I was wasting my time if I participated in extra activities designed to improve my employability.

11. It is important that I spend some of my time at University on developing my employability skills.

12. There may be better ways than specific employability classes for me to record the development of my employability skills.

13. There is NO value in trying to develop employability skills at University since they do not count towards my degree.

14. I think University career's fairs are useful.

15. I am not sure what skills employers are looking for.

16. I do not have a chosen career path so thinking about employability skills is a waste of time.

17. There will be plenty of time to think about employability when I have completed my degree.

18. I am always aware of the employability skills that I am developing during my University degree.

19. I am aware that the University has careers advisors that I can meet with.

20. I have been to visit a careers advisor since coming to University.

21. Meetings with potential employers would be more beneficial than employability skills classes.

22. There is scope to improve the way employability skills training is delivered on my course.

23. Employability skills do not increase the chance of getting a job. 


\section{Appendix C}

\section{Big-5; 50 item questionnaire}

1. I am the life of the party.

2. I feel little concern for others.

3. I am always prepared.

4. I get stressed out easily.

5. I have a rich vocabulary.

6. I don't talk a lot.

7. I am interested in people.

8. I leave my belongings around.

9. I am relaxed most of the time.

10. I have difficulty understanding abstract ideas.

11. I feel comfortable around people.

12. I insult people.

13. I pay attention to details.

14. I worry about things.

15. I have a vivid imagination.

16. I keep in the background.

17. I sympathize with others' feelings.

18. I make a mess of things.

19. I seldom feel blue.

20. I am not interested in abstract ideas.

21. I start conversations.

22. I am not interested in other people's problems.

23. I get chores done right away.

24. I am easily disturbed.

25. I have excellent ideas.

26. I have little to say.

27. I have a soft heart.

28. I often forget to put things back in their proper place.

29. I get upset easily.

30. I do not have a good imagination.

31. I talk to a lot of different people at parties.

32. I am not really interested in others.

33. I like order.

34. I change my mood a lot.

35. I am quick to understand things.

36. I don't like to draw attention to myself.

37. I take time out for others.

38. I shirk my duties.

39. I have frequent mood swings.

40. I use difficult words.

41. I don't mind being the centre of attention.

42. I feel others' emotions.

43. I follow a schedule.

44. I get irritated easily.

45. I spend time reflecting on things.

46. I am quiet around strangers.

47. I make people feel at ease.

48. I am exacting in my work. 
49. I often feel blue.

50. I am full of ideas 


\section{Appendix D}

\section{Student and staff attitude to employability questionnaire}

\section{Students version:}

1. I appreciate the value of employability elements in the curriculum.

2. Employability is an unnecessary element in my academic life.

3. Employability is imposed upon me by the university.

4. Employability element has a high pedagogic value for me in terms of my learning and development.

5. Motivation is much more important in succeeding in the future than employability skills.

6. There are too many students and not enough staff to deliver a meaningful employability element in the curriculum.

7. Employability is a very important part of my learning.

8. My tutors have sufficient knowledge about employability to deliver this element.

9. I feel involved in the employability aspect of essential skills module.

10. I benefit from employability elements in my curriculum.

11. Employability without a good job market is waste of time and money.

12. Employability skills are irrelevant for my future job prospects.

13. It is my responsibility to actively look for a job.

14. Employers are more interested in students' degree classification than their employability skills.

15. Employability skills will not increase my chance of getting a job.

\section{Staff version:}

1. Employability is an unnecessary element in the academic life of the student.

2. Students appreciate the value of employability elements in the curriculum.

3. Employability is imposed upon students by the department.

4. Employability element has a high pedagogic value for the students.

5. Student motivation is much more important in succeeding in the future than their employability skills.

6. There are too many students and not enough staff to deliver a meaningful employability element in the curriculum.

7. Employability is a very important part of student learning.

8. I have sufficient knowledge about employability to deliver this element.

9. The department offers enough training and support to its staff to deliver employability elements.

10. I have enough time to engage with and develop employability skills of my students.

11. I am involved in the department's employability programme.

12. The students can really benefit from employability elements in their curriculum.

13. Staff should be given the opportunity to get engaged in the development of employability skills of their students.

14. Employability without a good job market is waste of time and money.

15. Employability skills are irrelevant for students future job prospects.

16. It is the responsibility of the student to actively look for jobs .

17. Employers are more interested in students' degree classification than their employability skills.

18. Employability skills do not increase the chance of getting a job. 


\section{Appendix E}

Table 1: Prediction of engagement and understanding of and attitudes to employability by Big-5 personality traits

\begin{tabular}{|c|c|c|c|}
\hline GENERAL ENGAGEMENT & $\boldsymbol{B}$ & $S E$ & $\boldsymbol{\beta}$ \\
\hline Constant & -2.37 & 17.60 & \\
\hline Extraversion & 0.29 & 0.14 & $0.20 *$ \\
\hline Agreeableness & 0.69 & 0.23 & $0.31 * *$ \\
\hline Conscientiousness & 0.52 & 0.17 & $0.31 * *$ \\
\hline Emotional Stability & 0.03 & 0.14 & 0.02 \\
\hline Imagination & 0.43 & 0.28 & 0.16 \\
\hline \multicolumn{4}{|l|}{ COGNITIVE ENGAGEMENT } \\
\hline Constant & 0.47 & 10.83 & \\
\hline Extraversion & 0.15 & 0.09 & 0.17 \\
\hline Agreeableness & 0.45 & 0.14 & $0.34 * *$ \\
\hline Conscientiousness & 0.29 & 0.11 & $0.29 * *$ \\
\hline Emotional Stability & -0.01 & 0.09 & -0.01 \\
\hline Imagination & 0.16 & 0.17 & 0.10 \\
\hline \multicolumn{4}{|c|}{ BEHAVIOURAL ENGAGEMENT } \\
\hline Constant & 0.05 & 5.03 & \\
\hline Extraversion & 0.10 & 0.04 & $0.25^{*}$ \\
\hline Agreeableness & 0.14 & 0.07 & $0.22 *$ \\
\hline Conscientiousness & 0.15 & 0.05 & $0.32 * *$ \\
\hline Emotional Stability & 0.00 & 0.04 & 0.01 \\
\hline Imagination & 0.16 & 0.08 & $0.21 *$ \\
\hline \multicolumn{4}{|l|}{ EMOTIONAL ENGAGEMENT } \\
\hline Constant & -2.89 & 4.12 & \\
\hline Extraversion & 0.05 & 0.03 & 0.15 \\
\hline Agreeableness & 0.11 & 0.06 & 0.23 \\
\hline Conscientiousness & 0.08 & 0.04 & 0.22 \\
\hline Emotional Stability & 0.03 & 0.03 & 0.09 \\
\hline Imagination & 0.11 & 0.07 & 0.19 \\
\hline $\begin{array}{l}\text { UNDERSTANDING } \\
\text { EMPLOYABILITY }\end{array}$ & & & \\
\hline
\end{tabular}




\begin{tabular}{llll}
\hline Constant & 39.36 & 17.68 & \\
Extraversion & 0.13 & 0.14 & 0.10 \\
Agreeableness & 0.58 & 0.23 & $0.30^{*}$ \\
Conscientiousness & 0.15 & 0.17 & 0.10 \\
Emotional Stability & 0.25 & 0.14 & 0.20 \\
Imagination & 0.35 & 0.28 & 0.15 \\
\hline ATTITUDES TO & & & \\
EMPLOYABILITY & & & \\
\hline Constant & 20.81 & 13.42 & \\
Extraversion & 0.07 & 0.11 & 0.07 \\
Agreeableness & 0.33 & 0.18 & 0.22 \\
Conscientiousness & 0.24 & 0.13 & 0.21 \\
Emotional Stability & 0.29 & 0.11 & $0.30^{* *}$ \\
Imagination & 0.23 & 0.21 & 0.12 \\
\hline
\end{tabular}

${ }^{*} p<.05, * * p<.01, * * * p<.001$, 